\title{
Going “Green" at Mulberry: Managing Brand Transitions
}

\author{
Tanvi Sakhamuri \\ Saks Fifth Avenue \\ Herbert Sherman \\ LIU- Brooklyn
}

\begin{abstract}
This case study looks at the difficult transition that was made by brand Mulberry from 'affordable luxury' to high-end luxury. This transition occurred during the reign of Bruno Guillon who was a former top manager at Hermes and was trying to convert the brand's image into one that could compete at the same level as his former company. Some of the strategies implemented were unsuccessful causing Bruno Guillon to resign from the company leaving it with an unsteady image. The brand since then has been trying to transition back to affordable luxury, as it was the market where they were known to be the most successful. A number of theories and models have been used to analyse the company during the transition to look at their problems and the actions they took to correct those mistakes.
\end{abstract}

\section{Introduction}

A young Englishman named Roger Saul founded Mulberry in 1971. In its short history, it has developed from a small business selling leather handicrafts to an international fashion brand aspiring to luxury status. As a young 16-year-old, Saul became interested in leather through visiting his dad's factory on Saturday mornings. He had also started to collect old military uniforms, while still a pupil at Kingswood boarding school in Bath. He took them to the Portobello Road market in London and sold them there at a profit.

In 1971, for his $21^{\text {st }}$ birthday, his father gifted him $£ 500.00$ and Mulberry was effectively born. (https://www.mulberry.com/us/about-us/modern-heritage, 6/6/19) Coming from a traditional rural English background the vision of the brand was affordable, but high quality leather accessories. The Mulberry name was chosen because a large, shapely Mulberry tree grew in the grounds of his old school. All the family supported Saul's new venture. His sister Elizabeth, who was a young graphic designer, created the logo, his father continued to give advice on leather, his mother joined as his business partner to do the administration and management and his then girlfriend sewed the items that Saul designed and cut out on the family kitchen table.

By 1979, the business was fully established and prospering. The company set up headquarters in Somerset and opened a London office/showroom in the trendy Carnaby Street, from which clothing was wholesaled to the London retail trade. Saul always believed that there was a lucrative international market for products with an "English" heritage and provenance, and his was one of the few brands to achieve early success in the challenging German market. In 1979, sales reached $£ 1.4 \mathrm{~m}$ and pre-tax profits of $£ 225,000$. Encouraged, Saul launched the brand in the United States, wholesaling it to department stores. The following year (1980), the first Mulberry store opened just of Oxford Street in London, followed by one in Paris.

Mulberry became a thriving company in the UK due to its strong British heritage, similar to that of Burberry's, and had positioned themselves in the affordable luxury category. There were few competitors in market segment that was popular amongst the youth of the country who were striving to purchase luxury products yet did not have the means to afford higher end brands such as Louis Vuitton and Dior. Bruno Guillon joined the company in March 2012 where he took the position of CEO.As soon as he joined Mulberry; he wanted to transition the brand to have a higher luxury status, which ended up being unsuccessful.

For the purposes of this case study, we will be looking at the transition of the brand mostly based on the time that Bruno Guillon was CEO. We will look at the success of the brand before he joined the company, the changes he made during his leadership and the problems it may have caused the company and finally we will look at the instability of the brand once he stepped down.

\section{Losing Their Way}

The brand went through several major changes over the years. First was the change of leadership. Bruno Guillon wanted to move the firm's market position to luxury status and that required brand conversion. His attempt resulted in the creative director leaving and ultimately failed. 
A new CEO was appointed as well as a new creative director. They both faced numerous obstacles and the firm is still recovering from all the past failed changes. The major changes are listed below in chronological order:

1. Bruno Guillon becoming CEO of Mulberry in 2012.

2. Emma Hill stepping down as creative director of the brand in 2013 due to creative differences.

3. Bruno Guillon stepping down as CEO in 2014.

4. Thierry Andretta becoming CEO in 2015.

5. Johnny Coca joined Mulberry in 2015 as the new creative director. (https://www.mulberry.com/us/aboutus/creative-director)

These two positions (CEO and creative director) are two of the most important positions in any fashion company. These changes in these positions in such a short period has caused a huge strain on the brand. The brand, during Guillon's tenure as CEO, had its share price drop by $67 \%$ and after he left the company, the brand only started recovering has since faltered in 2019. (See below summary of financials, Table 1)

Table 1: Mulberry Summary of Financials

\begin{tabular}{|llllll|}
\hline Year ended 31 March & $\mathbf{2 0 1 5}$ & $\mathbf{2 0 1 6}$ & $\mathbf{2 0 1 7}$ & $\mathbf{2 0 1 8}$ & $\mathbf{2 0 1 9}$ \\
\hline Revenue (GBP million) & 148.7 & 155.9 & 168.1 & 169.7 & 166.3 \\
\hline Adjusted PBT (GBP million) & 4.5 & 6.8 & 8.6 & 8.0 & 1.0 \\
\hline Statutory PBT (GBP million) & 1.9 & 6.2 & 7.5 & 6.9 & -5.0 \\
\hline $\begin{array}{l}\text { Adjusted Earnings Per Share } \\
\text { (GBp) }\end{array}$ & 2.1 & 5.4 & $10 . \mathrm{p}$ & 10.0 & 0.9 \\
\hline $\begin{array}{l}\text { Basic earnings per ordinary share } \\
\text { (GBp) }\end{array}$ & -2.3 & 4.5 & 8.4 & 8.3 & -8.2 \\
\hline Dividends Per Share (GBp) & 5.0 & 5.0 & 5.0 & 5.0 & 5.0 \\
\hline
\end{tabular}

https://www.mulberry.com/us/investor-relations/reports, 9/10/19.

There have been a number of mishaps along the way during the firm's transitions; most notably the CEO's planned changes for the firm.

Prior to Guillon's appointment, Mulberry was recognized as one of London's most high-profile brands, resonating with fashion followers, celebrities and professional women. Its bags had widespread appeal, particularly the Alexa satchel - which caused its profits to soar - and its catwalk shows were known for their starry front rows, including Kate Moss, Michelle Williams and Lana Del Ray. (Alexander, 2014)

Emma Hill was a successful creative director for the brand as she was the one that designed the famous 'Alexa' satchel (see Image 1) among other popular bags that were hugely favored by their consumers. After joining Mulberry, Guillon increased the brand's prices to try to make Mulberry a serious luxury contender. Due to this, Mulberry lost their quintessential youthful appeal, and therein-creative designer Hill, and made the brand seem to have an unclear direction in their consumers' eyes. "His [Guillon] mistake was attempting to fix something that wasn't broken." (Cochrane, 2014)

Image 1: Alexa Satchel

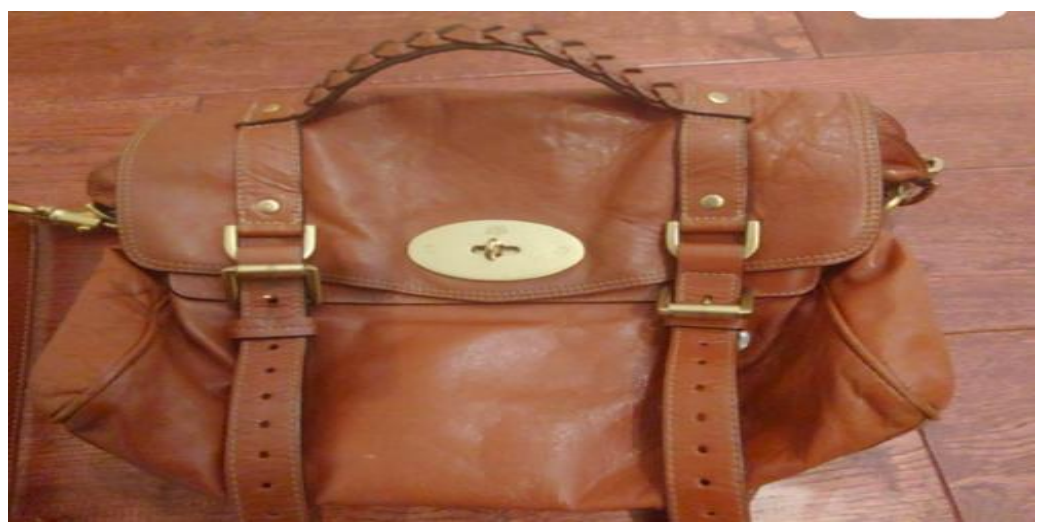

https://www.ebay.com/itm/Mulberry-AlexaSatchel/183950502849?hash=item2ad44debc 1:g:

NQAAAOSwWnpdAVH4 


\section{Transitions - An Overview}

Transitions are something that people face in everyday life and are something that businesses are constantly facing in order to keep themselves relevant and successful. The transitions faced by Mulberry were of a high magnitude and they were not handled in a way that made it easy for the employees as well for the consumers to adapt to.

In the analysis section of this case study, we will examine how the brand transitioned through the three important stages of organizational transition looking at each phase of the transition to see what went wrong and what they could have done differently. We will also look at where the brand is in 2019 and the problems they are still facing due to past problems.

To analyze the transitions that Mulberry has gone through over the years, a three-time period SWOT analysis has been conducted. The three times that are being examined are:

1. The brand before Bruno Guillon took over.

2. The brand during the period Bruno Guillon was in charge and his attempted conversion to a luxury brand.

3. The brand after Bruno Guillon stepped down as CEO.

\section{Before the Change}

In Table 2 below, you can see the SWOT analysis that has been conducted of the brand before Guillon joined the firm as CEO. This SWOT analysis indicates more strengths and opportunities for the brand than weaknesses and threats. Their biggest weakness was that the brand did not have a high presence outside the UK but expansion could have been considered. Their biggest threat at the time was the economic imbalance that the UK was facing as indicated in retail sales volume and low consumer confidence. (https://ig.ft.com/sites/numbers/economies/uk/) This imbalance luckily had not affected the fashion industry since the industry grew from 21 billion pounds in 2009 to 26 billion pounds in 2014.(https://www.statista.com/statistics/292019/value-of-fashion-industry-to-uk-economy/) Consumers though could have down shifted their purchases either cutting back on luxury goods(i.e. designer bags and clothing)or purchasing affordable luxurious items.

Table 2: SWOT analysis of Mulberry before CEO Bruno Guillon

\begin{tabular}{|l|l|}
\hline Strengths: & Weaknesses: \\
-British Heritage & $\begin{array}{l}\text {-Not well known outside the UK } \\
\text { - Non-existent marketing strategies } \\
\text {-Good Quality } \\
\text {-Not too many competitors in the affordable luxury } \\
\text { category }\end{array}$ \\
\hline $\begin{array}{l}\text { Opportunities: } \\
\text {-Building a global presence }\end{array}$ & $\begin{array}{l}\text { Threats: } \\
\text { - Economic imbalances during the time } \\
\text {-Increase use of digital marketing } \\
\text {-Creation of a second line to reach a new target } \\
\text { audience }\end{array}$ \\
\hline
\end{tabular}

As per the SWOT table, the brand actually had a lot of room to grow if the firm stayed in the affordable luxury market. (See Sherman et. al, 2006; when S>W; O>T the firm has growth potential.) Since the brand already had an established reputation in that category, the logical strategy would have been to expand their sales through concentration (sell more of the same products to similar customers) and market expansion (increase the target market to different regions with customers who valued British brands) (Sherman et. al, 2006).

\section{Guillon Era}

The first change, the process that started the firm's transition, occurred when Bruno Guillon was appointed CEO. A SWOT analysis of the firm after his appointment can be seen below in Table 3. Some of the same strengths and opportunities from before the change of CEO exist but there were now more weaknesses and threats then before. Guillon tried to transform the brand into a high-end product line and failed because he did it in the way that made it difficult for consumers to see the new brand proposition in its new market position. A transition of this nature needed to be implemented in a leisurely progression where the prices of products were increased slowly over a long period of time, as well as having marketing support adding to the greater differentiation of the brand. This was not the case with Mulberry. The new collection was created where the prices were drastically increased (from three to four figures) and that caused confusion amongst the sales employees as well as with their loyal customer base. The brand tried to attract a luxury audience, typically people with a high income and mostly women above the age of 30 . 
The products they created however were trendy and youthful and would be products that normally attracted an age range of 18-25 years; a group who historically could not afford luxury price points.

For example, Guillon created a capsule collection with Cara Delevingne (see Image 2), one of the biggest models at the time, and had an immense young following on social media.

Image 2 - Leather Jacket - Mulberry Capsule Collection

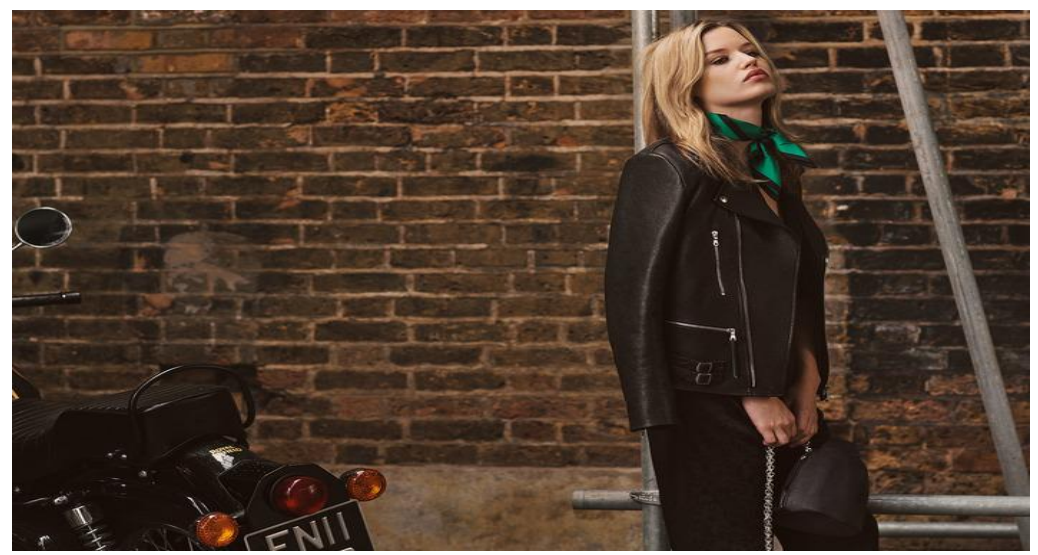

https://legattolifestyle.com/mulberry-capsule-collection-by-georgia-may-jagger/

Once again, the following that Cara Delevingne had was mainly ages 18-25 years. Consumers that were big fans of hers wanted to purchase the capsule collection but were not able to due to the fact the prices of the products were so high (nearly 1000 pounds for the jacket, 400 pounds for the pocketbook) and they were not able to afford them. This resulted in the capsule collection being unsuccessful.

There were also a number of other problems that occurred during his tenure such as the fact that Emma Hill the Creative Director of the brand stepped down due to creative differences. She was the one that created the famous Alexa satchel and she embodied the creative direction of the brand. After leaving, the brand was left without a creative director for two years, causing a huge confusion in brand identity and direction.

Table 3: SWOT analysis of Mulberry when Bruno Guillon joined Mulberry

\begin{tabular}{|c|c|}
\hline $\begin{array}{l}\text { Strengths: } \\
\text {-British Heritage } \\
\text {-Higher prices means more profit } \\
\text {-Good Quality } \\
\text {-Use of current models that have a high social media } \\
\text { presence }\end{array}$ & $\begin{array}{l}\text { Weaknesses: } \\
\text {-Not well known outside the UK } \\
\text {-Marketing techniques not in line with the brand image } \\
\text {-Confused target audience }\end{array}$ \\
\hline $\begin{array}{l}\text { Opportunities: } \\
\text { - Building a global presence } \\
\text { - Increase use of digital techniques } \\
\text {-Creation of a second line to reach a new target } \\
\text { audience }\end{array}$ & $\begin{array}{l}\text { Threats: } \\
\text {-Lose of customers that were only able to afford the } \\
\text { bags before the change in price } \\
\text {-Quality may not be up to the luxury level } \\
\text {-High number of barriers to enter the luxury market }\end{array}$ \\
\hline
\end{tabular}

\section{Post-Guillon Era}

The SWOT in Table 4below shows the brand's position after Bruno Guillon stepped down as CEO. The brand had an unsure direction with no idea on whether it is going to continue trying to aspire to luxury status and compete amongst brands like Hermes and Dior or whether the brand was going to be transitioned back to affordable luxury. There still was confusion over the brand's image causing consternation in consumers as well as in investors' eyes. The stock price of the brand had drastically decreased to nearly 670 pounds in 2014 (from its all-time high in 2004 of over 2000 pounds) increased to almost 1200 pounds in 2017 and has dropped below 300 pounds in 2019. (https://finance.yahoo.com/quote/MUL.L) 


\section{Table 4: SWOT analysis of Mulberry after Bruno Guillon left Mulberry}

\begin{tabular}{|l|l|}
\hline Strengths: & Weaknesses: \\
- Good Quality & -Not well known outside the UK \\
-British Heritage & -Confused brand image \\
-Not too many competitors in the affordable luxury & -Confused target audience \\
category & -No proper creative direction \\
\hline Opportunities: & Threats: \\
- Building a global presence & -Brand doesn't fit into not the affordable luxury or the \\
- Increase use of digital techniques & luxury category \\
-Creation of a second line to reach a new target & -Instability with the company \\
audience & -Confused brand marketing techniques \\
\hline
\end{tabular}

As denoted in the SWOT analysis, there a number of threat and weaknesses. Mulberry has not had taken the opportunity to convert back to an affordable luxury brand and is still facing problems in their transition. There is no clear direction to the brand and no idea to what sort of products they plan on developing.

Another to understand what occurred at Mulberry is to analyze the changes at Mulberry using Bridges \& Bridges (2016) three phases of transition model (see in Image 1 below). These three phases can be used to see how the shifting of Mulberry's brands value proposition and market position caused problems with both the employees and their consumers.

\section{Image 3: The Three Phases of Transition (Source: Bridges \& Bridges, 2016:05)}

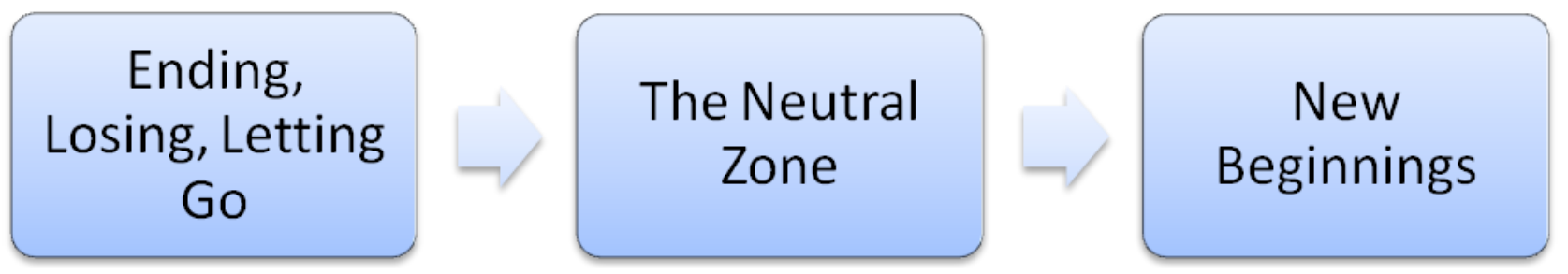

When Mulberry tried transitioning into a Luxury brand they went through the first phase of "ending, losing, letting go." In this phase, there was a need for management to facilitate the process of both the employees and customers letting go of Mulberry's affordable luxury image. The problem with this transition was that it was implemented in a manner that was too drastic and too quick. There was no time for "mourning" over the loss of the old brand image and no support for those employees and consumers. Employees and consumers needed to be educated as to why the change was 'the right thing to do' for the firm and the brand and how they could be part of the change process. Both stakeholders also needed to understand the benefits of the move and the firm needed to acknowledge that some of their employees and consumers would not be able to make such a transition (i.e. Emma Hill stepping down as creative director of the brand in 2013).

The "neutral zone" is the in-between time when the old is gone but the new is not operational yet. The brand was still trying to find its groove as a luxury brand and therefore this was a time where risks could be taken by the firm in redefining their market position and value proposition. This is the time when employees and consumers could have actively molded the new brand if they were allowed to be part of the brand development process. Bruno Guillon's capsule collection seemed to have missed the mark with their old consumer base and did not appeal to the more unscaled marketed they targeted. It was clear to Mulberry's Board that Guillon was not the leader who could successfully manage the firm in this phase of its transition and therefore the firm sought new leadership in Thierry Andretta becoming CEO and Johnny Coca as the new creative director in 2015.

"New beginnings" occurred with Mulberry's introduction of its hallmark color in 2015, Mulberry Green, an attempt to solidify its luxury brand position through product differentiation. This epitomized Creative Director Johnny Coca's ethos: to draw on the roots of the brand, but to offer a new point of view. Born from their heritage and their values, it was a combination of classic, but also modern design - a piece of future history. Mulberry green is emblematic of the firm's commitment to social responsibility. Mulberry Green (see Image 4) has been used for all of their packaging. All their Mulberry Green packaging is made from paper produced in England's Lake District, on the banks of the River Kent. At least $50 \%$ of its raw material comes from post-consumer content, to reduce impact on the environment. The remaining $50 \%$ is sourced from sustainably managed forests. It is a new shade of British Racing Green; the rich hue is used as the motor racing color of the United Kingdom. 
Mulberry Green evokes layers of history and the roots of the brand as Roger Saul, Mulberry's founder, had a passion for racing classic cars. Mulberry Green is evocative of a love of the English countryside and the beauty of its landscape. The shade, mixed with high levels of blue pigment and rich yellow, was developed with paper merchant G. F. Smith - a British specialist with over 130 years' experience. Mulberry Green even adorns the insoles of their shoes and the lining of their outerwear, an ever-present reminder of Mulberry's identity. (https://www.mulberry.com/us/about-us/mulberrygreen)

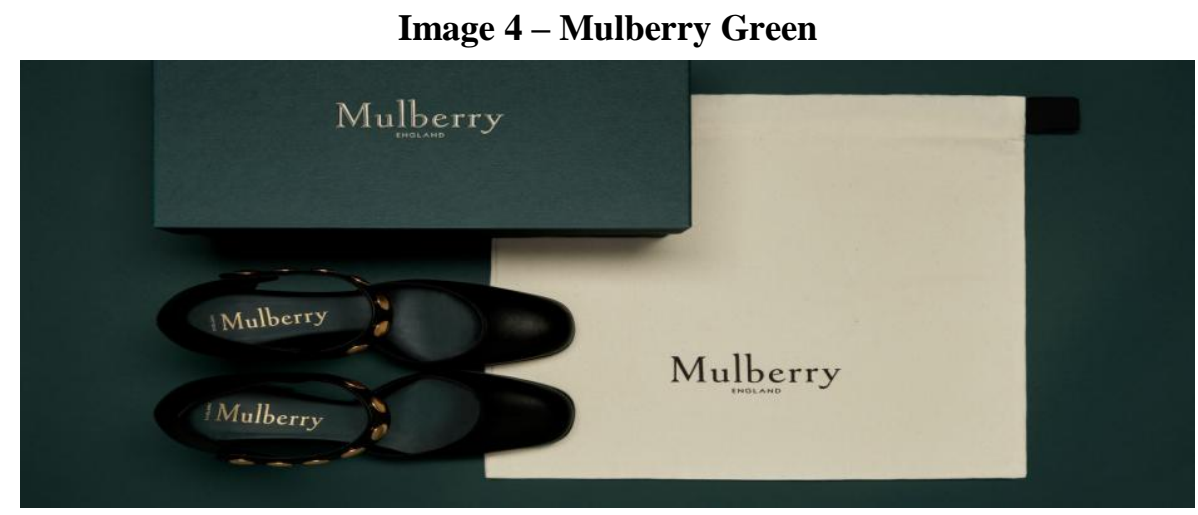

https://www.mulberry.com/us/about-us/mulberry-green

\section{Final Comments}

It is clear by examining Mulberry's financials that their new beginnings in 2015 created a major turnaround for the firm, going from negative 2 pounds per earnings per share to positive 8 pounds per share in 2018 . However, 2019 has been a disappointing year since one of its major retailers, House of Fraser, went into bankruptcy. Mulberry is one of more than 1,000 suppliers that will not receive payments owed by House of Fraser, and was the first with a concession to confirm the financial impact of the chain's collapse. (https://www.theguardian.com/business/2018/aug/20/mulberryhouse-of-fraser-profits) The firm though continues to pursue its luxury growth strategy focusing on expansion into China, Hong Kong, Taiwan and Japan.

In June, Thierry Andretta, its chief executive, said that while the company was "totally committed" to the UK market, he hoped the split between UK and international sales would be closer to 50/50 in the long term.... Trading in the rest of the world continues to develop broadly in line with management's expectations.... The group is in a strong cash position and continues to follow its strategy to develop Mulberry into a global luxury brand." (https://www.theguardian.com/business/2018/aug/20/mulberry-house-of-fraser-profits)

\section{References}

Alexander, E. (2014).Mulberry CEO Resigns.www.vogue.co.uk, 6/6/19

Armstrong, A. (2015). Mulberry's new creative director finally arrives. www.telegraph.co.uk, 6/6/19.

Bridges, S \& Bridges, W. (2016). Managing Transitions: Making the Most of Change. Boston: De Capo Lifelong Books.

Cochrane, L. (2014).Bruno Guillon's resignation from Mulberry comes as no surprise.www.theguardian.com, 6/6/19.

Kapferer, J. (2015). Kapferer on Luxury: How Luxury brands can grow yet remain rare. Philadelphia: Kogan Page Limited.

Mau, D. (2015).Mulberry Finally Names a CEO.www.fashionista.com, 6/6/19.

Sherman, H., D. J. Rowley and B. Armandi (2006). Strategic Management: An Organizational Change Approach. Lanham, MD: University Press of America.

https://finance.yahoo.com/quote/MUL.L, 9/11/19.

https://ig.ft.com/sites/numbers/economies/uk/, 9/11/19.

https://www.mulberry.com/us/about-us/creative-director, 9/11/19.

https://www.mulberry.com/us/about-us/modern-heritage, 6/6/19.

https://www.mulberry.com/us/about-us/mulberry-green, 9/11/19.

https://www.statista.com/statistics/292019/value-of-fashion-industry-to-uk-economy/, 9/11/19.

https://www.theguardian.com/business/2018/aug/20/mulberry-house-of-fraser-profits, 9/11/19. 